\title{
RECYCLING OF SEWAGE IN AQUACULTURE: AN OVERVIEW
}

\author{
Deeksha Singh and Radha Chaube* \\ Department of Zoology, Institute of Science \\ Banaras Hindu University, Varanasi (U.P.), India \\ ${ }^{*}$ Corresponding author: chauberadha@rediffmail.com
}

Article Info:

Review Article

Received

10.09.2021

Reviewed

15.10.2021

Accepted

25.10.2021

\begin{abstract}
Sewage contains huge quantities of different types of nutrients which are utilized in fish culture; hence recycling of this wastewater in a productive way is the acute demand of the future of aquaculture. Raw sewage cannot be used for a fish culture so it is treated at 3 levels namely mechanical, chemical and biological. These treatments reduce the microbial contaminants load and optimize the physicochemical parameters of sewage. Different aspects of fish farming such as seed quality, species selection, stocking density, harvesting technique, and marketing of fishes were considered. Various kinds of fish species cultured including Catla catla, Heteropneustes fossilis, Tilapia mossambicus are almost safe for human consumption after following the guidelines of WHO. Sewage fed culture has boundless potential in the field of aquaculture to solve the water scarcity problems and increased farm income.
\end{abstract}

Keywords: Aquaculture, Aquatic ecosystem, Recycling, Sewage.

\section{INTRODUCTION}

As the population is tremendously increasing, scarcity of water is one of the major problems that people are facing worldwide. It is predicted that water available in 2001 was 1820-1902 m3/year which may reduce to $1401 \mathrm{~m} 3$ /year by 2025 (Gupta and Deshpande, 2004; Sharma, 2005). Hence, it is a serious need to utilize this precious resource through proper management and formulation of well-planned strategy (Mandal et al., 2015). Hundred liters of wastewater in the form of domestic sewage are discharged per person/day in and around Kolkata (Jana, 1998). This appears to be a similar scenario for all the metro cities in India. So, it is the need of hour to utilize this sewage water, which is one of the most important renewable resources that can be saved.
Sewage is water-carried waste; it contains an abundant quantity of nutrient elements such as nitrogen, phosphorus, potassium, and traces of zinc, copper, chromium, and manganese. It pollutes the water and is harmful to the fish and all the organisms, if used without treatment, due to very low oxygen content, high carbon dioxide and ammonia. Therefore, raw sewage is treated before its utilization in culture ponds for reduction of microbial load and contaminants by systematic treatments. It reduces the organic load and biochemical oxygen demand (BOD). The raw sewage is undergone a distinctive treatment procedure as per requirement. Sewage is responsible to bring changes in the quality of water and biological characteristics of sewage-fed aquaculture ponds. However, an appropriate 
amount of sewage intake is the assurance of sewage-fed aquaculture.

The technique of recycling sewage in aquaculture was first developed in Germany and later on independently used in Kolkata in 1930; the main agenda behind this technique is to manage the waste in order to utilize it in fish culture. It was established as one of the best operational systems in the world to convert the waste inconsumable product, the growing fish demand of the metro cities like Kolkata.

Water is life and pollution in it in any form is not beneficial for entire biotic community including humans (Prakash and Verma, 2020a, 2021; Singh, 2021; Kalal et al., 2021). It is used to irrigate the field and the wastes generated from these farms are used as supplementary feed for fishes. This is an integrated way of aquaculture which was proved very much profitable for the farmers. The use of sewage for fish culture is now practiced in Indian states like Bihar, Madhya Pradesh, Maharashtra and in countries like Poland, Hungary, Israel, Indonesia, Peru and so on.

The main objective is the utilization of sewage in fish farming but now the research is going on sewage related issues as classification, characterization, post-effects of sewage utility, and safe fish for consumption, health and hygiene of consumers. It provides a low cost technology to the fish farmers through sewage intake as a cheap external input in aquaculture.

\section{PROPERTIES OF SEWAGE}

Composition and concentration of domestic sewage vary greatly, with times and places therefore characterization of wastes is essential for an effective and economical waste management program. When raw sewage is treated properly, it reduces the undesirable physicochemical properties in one way and enhances the desirable properties. The factors that decide the treatment of sewage are temp, $\mathrm{pH}$, solar radiation, and the presence of predators (Raangeby et al., 1996). The treatment method discussed here plays an effective role as the microbial load may decline remarkably as total coliform and fecal coliform went down by $87 \%$ and $92.5 \%$, respectively. Total ammonia, BOD and phosphate were reduced by $88 \%, 80 \%$, and $71 \%$, respectively. It helps to choose the treatment methods deciding the extent of treatment, assessing the beneficial uses of wastes, and utilizing the waste purification capacity of natural bodies of water during a planned and controlled manner.

The characteristics of sewage can be classified as:

1. Physical characteristics

2. Chemical characteristics

3. Biological characteristics

\section{Physical Characteristics}

Color and Odor: Color is due to suspended and other matter found in freshwater. If sewage is suitable for use, it has a soap solution colour i.e. grey-brown and decomposed sewage has dark grey colour. Fresh sewage is of soapy or greasy but stale sewage has an unpleasant odor due to $\mathrm{H}_{2} \mathrm{~S}$, $\mathrm{CH}_{4}$.

Temperature: The observations of temperature of sewage are useful in indicating the solubility of oxygen, which affects the transfer capacity of aeration equipment in aerobic systems, and the rate of biological activity. In general, under Indian circumstance, the temperature of the raw sewage was observed to be between 15 and $35{ }^{\circ} \mathrm{C}$ at various places in different seasons.

Turbidity: It is very turbid than water due to the presence of high suspended and other particles.

\section{Chemical Characteristics}

Sewage contains complex compounds derived from urine, faces, inorganic chemicals etc. and it's different characteristics (table 1) are:

The pH: The $\mathrm{pH}$ of fresh sewage is slightly higher than the water supplied to the community. However, the decomposition of organic matter may lower the $\mathrm{pH}$ whereas the presence of industrial waste material may lead to extreme fluctuation (http://www.fao.org). Generally, the $\mathrm{pH}$ of raw sewage lies in the range of 5.5 to 8.0. 
Dissolved Oxygen (DO): It is the amount of oxygen dissolved in the wastewater. Its presence indicates the sewage is fresh or oxidation has occurred after treatment. It is necessary to ensure that at least $4 \mathrm{ppm}$ of dissolved oxygen in a stream in which treated wastewater is disposed of otherwise fishes are likely to die.

Biochemical Oxygen Demand (BOD): The BOD of the sewage is the amount of oxygen required for the biochemical decomposition of biodegradable organic matter under aerobic conditions. The oxygen consumed within the process is said to the quantity of decomposable organic matter. The general range of BOD recorded for raw sewage is 100 to $400 \mathrm{mg} / \mathrm{L}$.

Chemical Oxygen Demand (COD): It is defined because the amount of oxygen required for chemical oxidation of organic matter readily oxidizable carbonaceous and other matter. In general, the COD of raw sewage at various places is reported to be within the range of 200 to 700 $\mathrm{mg} / \mathrm{L}$.

Table 1: Selective physico-chemical parameters of sewage in different grades.

\begin{tabular}{|l|l|c|c|c|c|}
\hline Sl. No. & Parameter & Raw sewage & Treated sewage & $\begin{array}{c}\text { Moderate } \\
\text { sewage }\end{array}$ & Pond water \\
\hline 1 & $\mathrm{pH}$ & 6.1 & 7.0 & 7.5 & 7.5 \\
\hline 2 & Total solids & 720 & 250 & 200 & 80 \\
\hline 3 & Total alkalinity & 300 & 240 & 190 & 170 \\
\hline 4 & Total nitrogen & 25 & 15 & 10 & 1.0 \\
\hline 5 & $\mathrm{P}_{2} \mathrm{O}_{5}$ & 08 & 05 & 02 & 0.15 \\
\hline 6 & $\mathrm{BOD}$ & 400 & 200 & $80-100$ & $10-18$ \\
\hline
\end{tabular}

All the values except $\mathrm{pH}$ are in mg/L (Source: Mandal et al., 2015)

\section{Biological Characteristics}

Domestic sewage consists of various types of plant and animal microorganisms and the biological characteristics are related to them. The microorganisms whose numbers are 22-25 million in a liter may be a pathogenic indicator organism. The main source of the pathogenic indicator from excreta from sick people and this organism requires living tissue to grow and reproduce and harmful to man.

The microorganisms can be broadly classified as:

(a) Aquatic plants: consist of the water weed etc.

(b) Aquatic animals: consist of hydra, earthworm, insects, snails, fish, amphibians etc.

(c) Mould (fungi), bacteria and viruses: may also be aquatic but categorized separately.

Bacteria, play a pivotal role for decomposition of waste and are considered an integral component of organic matter, some are pathogenic, or disease- carrying, and pose a threat to public health. Pathogenic viruses that present in wastewater include polio and hepatitis. Various intestinal viruses are also found in sewage effluent. In contrast to bacteria, the amount of pathogenic viruses in sewage is little. A single infectious virus may found among an estimated million coliform bacteria.

\section{TREATMENT OF SEWAGE}

In aquaculture, sewage water can be utilized only when it is found suitable for its reuse. In order to make the sewage waste beneficial for aquaculture, following treatment is given:

\section{Mechanical Treatments:}

Raw sewage is first treated mechanically (fig. 1). It is subjected to screening in which large coarse particles (solid material) are removed, followed by skimming for floating solids. This process helps in removing fats, oils, grease and fine particles from the sewage and sedimentation (for suspended particles whose density greater than 


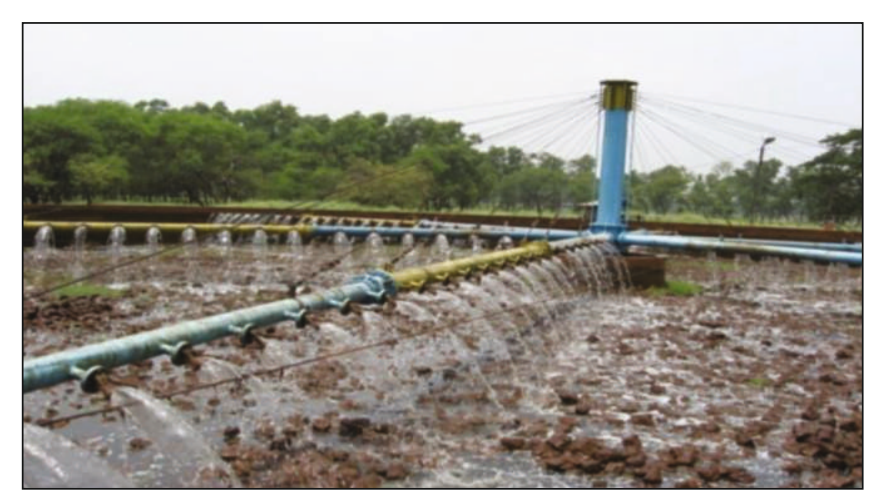

Fig. 1: Sewage Treatment (Mechanical Process). Source: https://www.academia.edu/

11497487/Sewagefed_aquaculture_system.

liquid). Sewage is allowed to run at high velocity through channels or pipes, and when it enters the large tank, there is sudden drop in velocity resulting in sedimentation.

\section{Chemical Treatments:}

- The chemical treatment of the sewage is done by using chlorine and copper sulphate for disinfection and deodorization.

- It is then allowed to stand in oxidation tank where bacterial decomposition causes oxidation of organic matter releasing carbon dioxide, which is used by algae for photosynthesis (fig. 2). Thick blooms appear in sewage water and lead to development of zooplankton.

- It is necessary to retain the sewage in stabilization or oxidation pond for 10-12 days till it becomes fit to discharge into the fishery ponds.

- Before adding sewage water to fishery ponds, it is diluted with fresh water to maintain the required dissolved oxygen content, ammonia and $\mathrm{H}_{2} \mathrm{~S}$.

- Treated sewage water is added to the fishery ponds at monthly intervals.

- Repeated chemical analysis of available treated sewage is done. If the chemical characterization of treated sewage is suitable it may be incorporated into rearing pond directly or kept putting in stabilized ponds temporarily or undergone a repeated biological treatment.

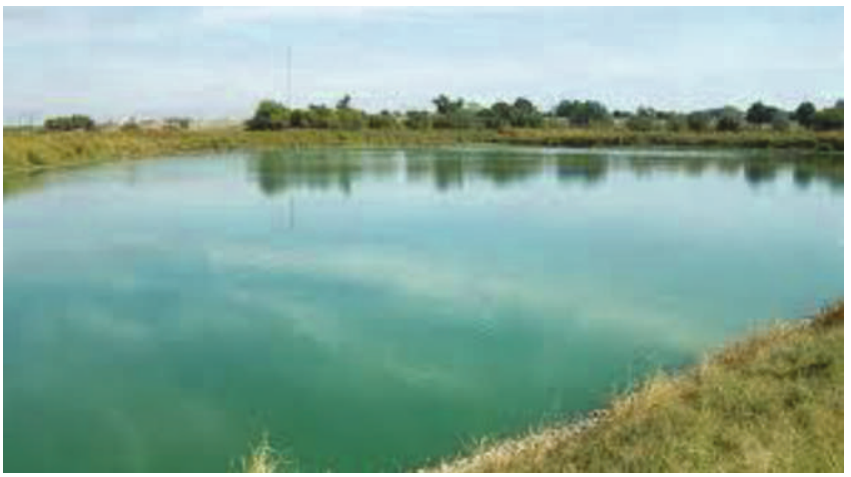

Fig. 2: Oxidation of Pond.

Source: https://core.ac.uk/download/ pdf/81079538

\section{Biological Treatments:}

Central Institute of Freshwater Aquaculture has designed and developed an Aquaculture Sewage Treatment Plant (ASTP) to include duckweed along with fish culture. Different stages of biological treatment using duckweeds are considered to be a viable technology for sewage treatment in the perspective of sustainable aquaculture (Oron, 1994; Ayyappan, 2000; Jena et al., 2010).

A set of duckweed ponds of size $25 \mathrm{~m} \times 8 \mathrm{~m} \times 1 \mathrm{~m}$ are constructed for the purpose, where algae and duckweed are allowed to grow (Khanna and Singh, 2014). The retention period of sewage in each duckweed-covered pond is normally 3-5 days (fig. 3). These plants help in removing heavy metals and other harmful chemicals and provide oxygen through photosynthesis (Culley and Epps, 1973). The plants used for the treatment of domestic sewage are Azolla, Spirodela, Wolffia, and Lemna. Once the pond is fully covered with a weed mat, $50 \%$ of the same would be harvested, allowing growing space for residual weeds (Ayyappan, 2000; Jena et al., 2010). The harvested weeds (fig. 4) can be used for feeding grass carp in the marketing ponds and excess weed can be converted into fertilizer as compost.

\section{Role of Macrophytes}

In this case, partially treated sewage is directed in aquaculture ponds. Periphery of the pond is roofed with water orchids. Such process of bioremediation of sewage water through aquatic macrophytes comprising taro, Typha angustata and eventually, water hyacinth was operated with 


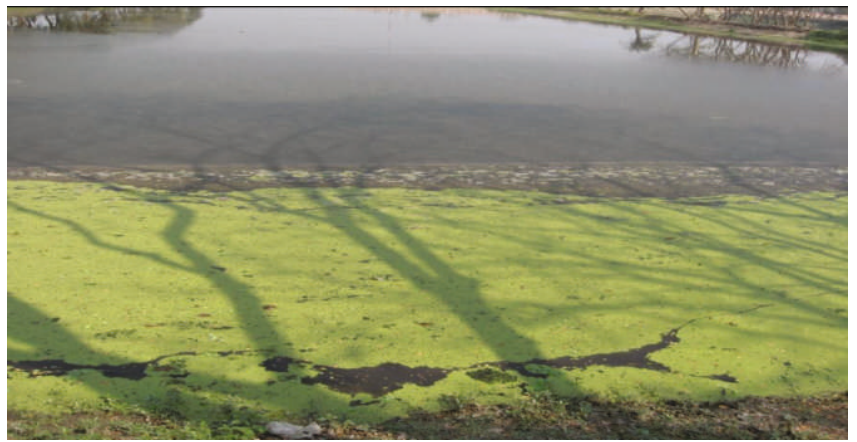

Fig. 3: Biological Treatment.

Source: https://www.academia.edu/ 11497487/Sewagefed_aquaculture_system

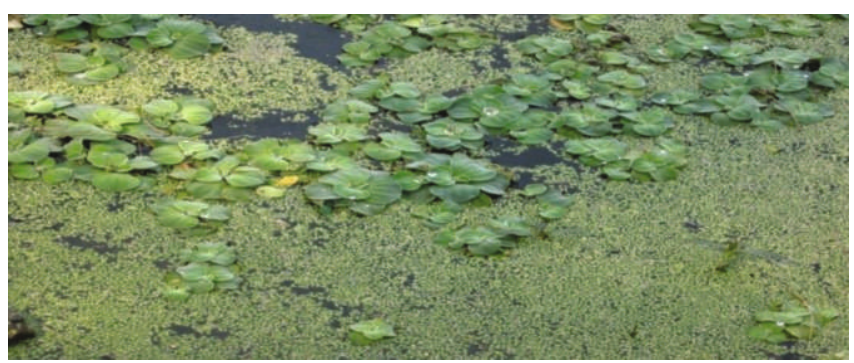

Fig. 4: Aquatic weeds (biological filter).

three-tier treatments. The macrophytes are the bioindicators (Singh and Singh, 2020). Colocasia $\mathrm{sp}$. vegetation is used to cover the major portion of wetland which can accumulate contaminants, including heavy metals. This way of treatment is quite efficient in reducing the levels of physiochemical parameters of sewage water (Mandal et al., 2016).

\section{Use of Trickling filter}

A trickling filter (fig. 5) is an attached growth process i.e. process during which microorganisms responsible for treatment are attached to inert packing. The packing utilized in attached growth processes include rock, gravel, slag, sand, redwood, and a good range of plastic and other synthetic materials.

The microorganisms absorb the organic matter within the sewage and stabilize it by aerobic

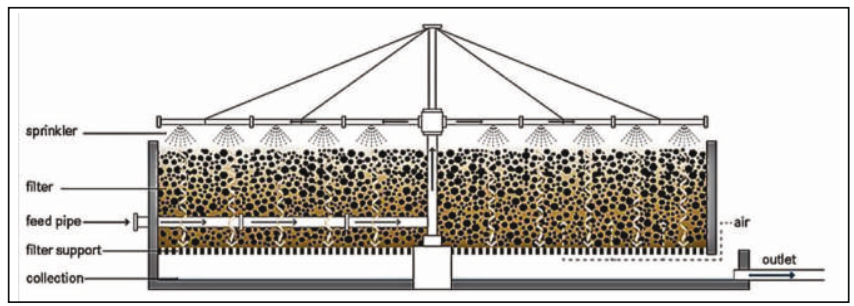

Fig. 5: Trickling filter.

Source: https://sswm.info/sanitation-

systems/sanitation-technologies/trickling-filter metabolism, thereby removing oxygendemanding substances from the sewage. Trickling filters remove up to 85 percent of organic pollutants from sewage.

\section{Fish farming technique in aquaculture}

Aquaculture comprises a number of interrelated steps for the cultivation of fish crop and their desirable yield and in sewage fed system sewage fed ponds which are locally called Bheries. These sewage-fed ponds are generally shallow and vary from $50 \mathrm{~cm}$ to $150 \mathrm{~cm}$. In general, farmers adopt following techniques:

a) Preparation of ponds

b) Primary fertilization

c) Fish stocking

d) Secondary fertilization

e) Harvesting of fish

When the pond preparation is completed, sewage is passed into the pond from the feeder canal through the bamboo sluice (fig.6). Initial fertilization of the pond is done by means of the introduction of fresh sewage effluent, which is taken into the pond up to $90 \mathrm{~cm}$. It is left to become stable for 15-25 days. The self-purification of sewage is possible in presence of atmospheric oxygen and sunlight. When the water colour turns into green due to photosynthetic activity, the pond is considered ready for stocking. Largely external fertilization is not used in the sewage-fed farming system. But the mahua oil cake used as the fertilizer in the pond when utilizes. The nutrients extant in the sewage water are abundant to fertilize the pond and helps in the production of sewage.

The photosynthetic activity within the pond is mainly responsible for the biological purification of the sewage. Once the water turns completely

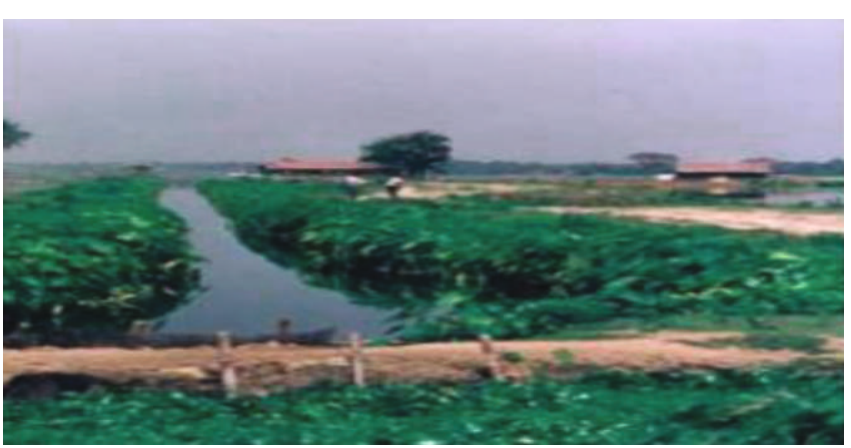

Fig 6: Open channel through which sewage is flown into pond

Source: https://www.slideshare.net/

ShreyosreeGanguly/sewage-fed-fisheries 
green, stocking of fry and fingerlings can be stocked. Before stocking fish, some fry are kept in hapas within the pond to check pond condition through survival. If the results are up to the mark, large-scale stocking is undertaken. As the sewage contains a high quantity of nutrients, the farmers keep a very high stocking density, i.e. 40,000 to 50,000 fingerlings/ha.

Quality of seed is very important to be considered for good aquaculture. The knowledge and awareness to produce and use good-quality seeds, along with regulations like certification/ accreditation of hatcheries, would go a long way to improve the quality of seeds produced in the country. All the species of Indian major carps e.g. Catla catla (Catla) Labeo rohita (Rohu), Cirrhinus mrigala (Mrigal), and Exotic carps e.g. Ctenopharyngodon idella (Grass carp), Hypophthalmichtys molitrix (Silver carp), Cyprinus carpio (Common carp) are preferred to be stocked but the share of Mrigal is added when exotic carps is lesser.

Fish farming requires an appropriate stocking density of fish to be reared either in monoculture or in polyculture (Chakraborty, 2020, 2021). Fish seeds should stock within the carrying size of sewage-fed aquaculture (Datta et al., 2000; Nandeesha, 2002; Edwards, 2008; Chakrabarti et al., 2011; Mandal et al., 2015). In general fingerlings of 10-15 g in size are stocked in sewage-fed pond culture (Datta et al., 2000).

After the application of sewage effluents, the BOD level of pond water rises considerably. The extent of increase depends on the amount of organic matter, enhances the primary productivity of the water through the release of nutrients. Phytoplankton starts appearing within 3 to 5 days of sewage application and generally continues to grow up to 15-20 days depending on the availability of nutrients. Due to the high content of nutrients in sewage, the cultured fish don't require any supplementary feeding. However, occasionally especially in the rainy season, when the potential sewage is lacking, they are fed with supplementary feed.

\section{Rotating Crop and Nursery Management System}

Farmers have evolved culture systems that are aware of market demand. Fish are stocked and harvested throughout the culture period resulting in periodical stocking and regular harvesting. In larger ponds, harvesting takes place continuously for almost fifteen days a month. After completion of 1 cycle of harvest during a large pond, fishes are restocked at the speed of $1 \mathrm{~kg}$ of fingerlings for each $05 \mathrm{~kg}$ of fish harvested. After restocking, fishes are left undisturbed for the next fortnight. Drag nets are most of the time used for harvesting fishes through an encircling technique.

A nursery is a facility where the fish seed (spawn, hatchlings, or fry) can grow. Nursery pond culture needs special preparation for receiving spawn and hatchlings. The ideal size is considered of a nursery is 0.02-0.05 ha with a depth of 1.0-1.5 m.

\section{Selection of Fish for Sewage-fed Pond}

Fish culture attracts the farmers because a large number of fishes are sewage tolerable. Such fishes are selected for sewage fed ponds so that they can survive with a low amount of dissolved oxygen content. Clarias batrachus, Heteropneustes fossilis, Channa spp., Tilapia mossambicus and Ctenopharyngodon idella (grass carp) are few examples of the species of choice to be considered for culture in sewage treated ponds.

Tilapia is most suitable fish for this type of culture because they have lesser demand of oxygen. Such fishes grow and breed in sewage ponds profusely. They can be cultured either as mono or polyculture with Clarias batrachus. Ghosh et al. (1980) reported a total production of $220 \mathrm{~kg} /$ hectare in a composite culture of Tilapia and Clarias sp.

Fishes are selected on the basis of carnivorous, herbivores, omnivorous and detritivorous feeding habit. The herbivores feed mainly on microalgae, phytoplankton and therefore they are the most efficient users of energy as they are directly feeding on producers. Detrivores feed on the dead decaying organisms that are found at the bottom of the pond. Carnivore fishes feed small- sized fishes, annelids, insect larvae, and molluscs. Omnivorous feed on both plant and animal matter. As these fishes have different food habits they do not interfere with other fish in their growth. In sewage-fed ponds, prawns, Indian carps, catfishes are selected to grow by determining the variable grade of sewage concentration that is best suitable for fishes.

\section{Integrated Wastewater Aquaculture}

Sewage fed aquaculture system can be integrated 
with livestock production, agriculture crop (fig. 7a) and horticulture. This is the integrated way of culture, which has the potential of offering effective wastewater treatment, economic returns as well as generating employment. This practice of using wastewater as a resource for the rural and urban areas is an important aspect of sustainable development (Yan and Honglu, 1989) because sustainable development with environmental ethics is the need of our long lasting survival (Verma, 2019, 2021).

On the embankment area of pond, plantation of banana (fig. $7 \mathrm{~b}$ ) and papaya are done that give good revenue source. Coconut trees are also planted on the farm and on average each plant produced about 50 coconuts in a year, and its productions would gradually increase. By using the dykes and other land areas of the pond obviously will increase the revenue earnings but it also needs to check that number of weeds should not increase. Duck and hen farming integration with fish farm is profitable so it is practiced in few places. The ducks and hens are used for protein production in form of eggs and dropping of ducks and hen can be utilized as the fertilizer for ponds. Goat and pig farming is also used as integration with fish farming. Pig rearing is highly promoted now days because pigs
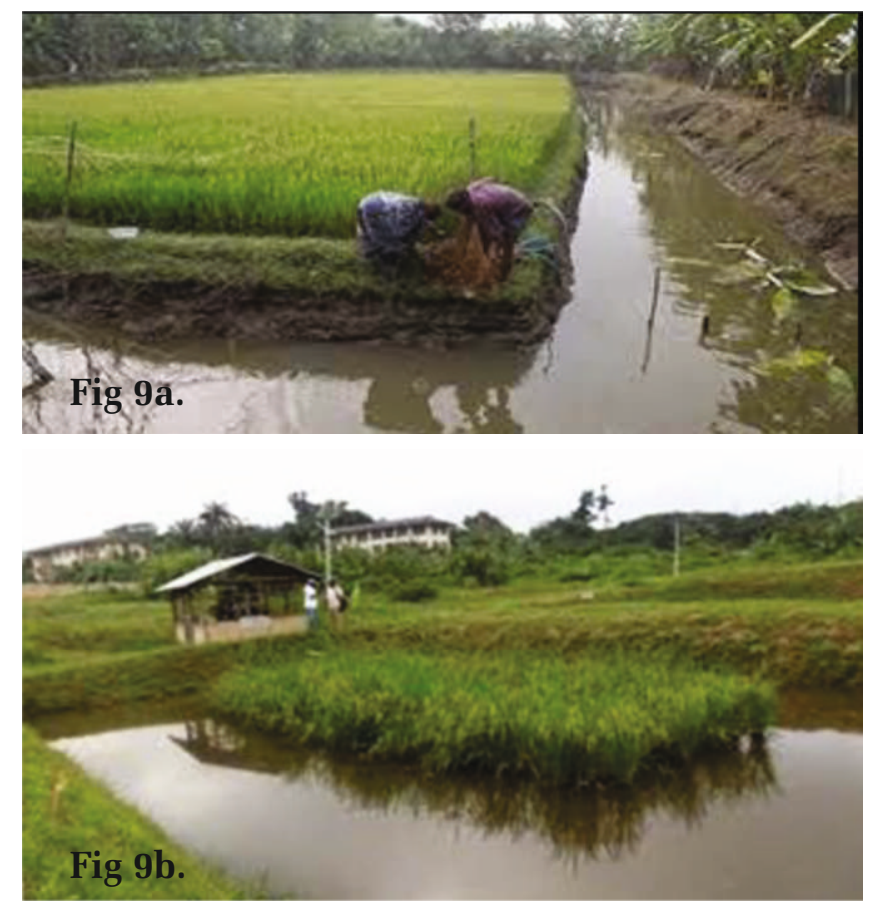

Fig $9(a, b)$ : Showing Integrated AgriAquaculture System.

Source: https://agricfarming.com/integrated basically feed on kitchen wastes, crop wastes, and aquatic plants.

\section{Heavy metals, Health care and Risk assessment}

Sewage is rich in organic substances and different concentrations (ppm) of many heavy metals like $\mathrm{Mn}, \mathrm{Cu}, \mathrm{Cr}, \mathrm{Zn}, \mathrm{Pb}$ vary in the range of 0.05-5.0. It is observed that primary treated sewage water contains a very low amount of heavy metals which is far below the permissible limit. Fishes reared in the sewage fed system are safe for human consumption. Bioremediation is one of the best techniques that is used to remove heavy metals by using macrophytes (Raychaudhuri et al., 2007; Sengupta et al., 2012).

It is necessary that sewage-fed water bodies need to undergo repeated treatment and analysis so that they can ensure that the water is suitable for culture regarding safety issues of consumers. The pesticides and electronic wastes are also found there (Verma and Prakash, 2018, 2020; Prakash and Verma, 2020b). The pesticides used in sewage-fed agriculture such as alpha- endosulfan sulfate, malathion, mancozeb, and carbaryl were analyzed from fish in sewage-fed aquaculture. Even though no residues of these pesticides were found at the limit of $0.01 / \mathrm{kg}$ of fish sample (Bhowmik et al., 1995).

In general, fishes are most vulnerable to bacterial disease, but surprisingly occurrence of bacterial or any other diseases is not common in sewagefed farms. There are some infection-causing worms such as Anchor worm and Argulus (fish lice) that are quite common but they are not given any kind of proper treatment. There is a need to develop few techniques so that this kind of disease doesn't affect the rearing.

WHO (2006) has recommended the bacterial quality standards and thresholds concentration for fish muscle. This is considered as the standard precautionary measure for aquaculture until any other authentic body generates any guidelines for this aquaculture rearing system to work properly.

Some advantages of sewage-fed aquaculture include: (a) low input cost and good production rate, (b) reduction in the pollution load of rivers and aquatic ecosystems, (c) richness of essential amino acids and proteins hence important in food 
security, and (d) income generation and upliftment in family livelihood as well as financial status.

\section{CONCLUSIONS}

Sewage in aquaculture serves two important purposes: (a) transformation of misplaced nutrients into fish biomass and (b) conservation within the context of accelerating freshwater scarcity. The sewage-fed culture could also be a low-cost process of fish culture with no manuring and supplementary feeding because of the high content of nutrients within the sewage.

The sewage contains a high load of organic and inorganic matters, toxic gases which cause lower dissolved oxygen contents. There is a chance of infection and pollutions entering into the human body through fish using raw sewage in the fish ponds. Hence a model of sewage-fed fish culture technique is advisable in which the sewage is treated properly. Ponds should be prepared and categorized according to the treatment techniques. Authors strongly recommend a screening and filtration of sewage before pouring into ponds. By adopting this system, it will be easy to avoid the environmental damage caused by untreated sewage.

\section{REFERENCES}

1. Ayyappan S. (2000). Duckweed and fish based aquaculture sewage treatment system: status and prospects. (In: Jana BB, Banerjee RD, Guterstan D, Heeb J; eds). Waste recycling and resources management in the developing world. University of Kalyani/India and International Ecological Engineering Society, Kalyani/Wolhusen.59-63p.

2. Bhowmik M.L., Pandey B.K. and Sarkar U.K. (1995). Influence of domestic sewage on fish and incidence of microbial population. In: Current and emerging Trends in Aquaculture, P.C. Thomas (ed.), Daya Publishing House, New Delhi. 35-38p.

3. Chakrabarti P. P., Ghosh P. K., Mukhopadhyay P. K. and Jayasankar P. (2011). Urban sewage water recycling through aquaculture. Everything about water. Sept.: 36-39.
4. Chakraborty B. K. (2020). Rearing and Nursing of Thai Pangas, Pangasianodon hypophthalmus (Sauvage, 1978) with different feeds. International Journal of Biological Innovations. 2 (2):277-286.

5. Chakraborty B. Kumar (2021). Induction of spawning and nursing pangas, Pangasianodon hypophthalmus (Sauvage, 1878) under hatchery system. International Journal of Biological Innovations. 3 (2): 264-270.

6. Culley D.D. and Epps E.A. (1973). Use of Duckweed for Waste Treatment and animal feed. J. Water Pollution Control Fed. 54(2):337347. http://www.jstor.org/stable/25037746

7. Datta A.K., Roy A.K. and Saha P.K. (2000) Comparative evaluation of sewage fed and feed based aquaculture. In: Jana BB, Banerjee RD, Guterstan D, Heeb J (eds) Waste recycling and resources management in the developing world. University of Kalyani/India and International Ecological Engineering Society, Kalyani/Wolhusen. 97-104p.

8. Edwards P. (2008). An increasingly secure future of wastewater fed aquaculture in Kolkata, India. Aquaculture Asia. Xiii: 3-9.

9. Ghosh A., Rao L. H. and Saha S. K. (1980) Culture prospects of Sarotherodon mossambicus in small ponds fertilized with domestic sewage. J Inland Fish Soc India. 12:79-80.

10. Gupta S. K. and Deshpande R. D. (2004). Water for India in 2050: first-order assessment of available options. Curr Sci. 86(9):12161224.

11. Jana B.B. (1998). Sewage-fed aquaculture: The Calcutta model. Ecol Engg. 11(1-4):73-85. https://doi.org/10.1016/S0925-8574(98) 00024-X.

12. Jena J.K., Patro B., Patri P., Khuntia C.P., Tripathy N.K., Sinha S., Sarangi N. and Ayyappan S. (2010). Biological treatment of domestic sewage through duckweed-cumfish culture: a pilot-scale study. Indian J. Fish. 57(4):45-51. 
13. Kalal V., Giri M.J., Baskar S. and Kuba R. (2021). Detection of Pollutants present in the surface water of Ayad River, Udaipur, Rajasthan. International Journal of Biological Innovations. 3 (1): 212-220. https://doi.org/ 10.46505/IJBI.2021.3123.

14. Khanna S.S. and Singh H.R. (2014). A Text book of Fish Biology and Fisheries $\left(3^{\text {rd }}\right.$ edition). Narendra Publishing House, Delhi. $610 p$.

15. Mandal R.N., Chakrabarti P.P. and Jayasankar P. (2015). Sewage fed aquaculture: a viable proposition for fish production through nutrients recovery and water conservation, in effect of abating water pollution. In: Singh RP, Sarkar A (eds) Waste management. Nova scientific Publication, USA.

16. Mandal R.N., Chattopadhyay D.N., Pandey B.K., Paul B.N., Chakrabarti P.P. and Jayasankar P. (2016). Promotion of sewagefed aquaculture through public private partnership. In: Sinha VRP Keshavnath P, Sharma AP, Mohanty BP (eds). Public Private Partnership in Aquaculture Narendra Publishing House, Delhi.

17. Nandeesha M. C. (2002). Sewage fed aquaculture systems of Kolkata- A century old innovation of farmers. Aquaculture Asia. $7(2): 28-32$.

18. Oron G. (1994). Duckweed culture for wastewater renovation and biomass production. Agric. Water Manag. 26(1-2):2740. https://doi.org/10.1016/03783774(94)90022-1

19. Prakash S. and Verma A.K. (2020a). Toxic Effects of Paper Mill Effluents on Mortality, Behaviour and Morphology of Snake Headed Fish, Channa punctatus (Bloch.). International J. of Biological Innovations. 2 (2): 102-108.

20. Prakash Sadguru and Verma A. Kumar (2020b). Effect of organophosphorus pesticides on Biomolecules of fresh water fish, Heteropneustes fossilis (Bloch). Indian Journal of Biology. 7(2): 65-69.
21. Prakash S. and Verma A.K. (2021). Effect of water pollutants on the Snake headed fish, Channa punctatus collected from the Sawan Nallaha, Balrampur, U.P. International Journal of Fauna and Biological Studies. 8(1): 38-42.

22. Raangeby M., Johansson P. and Pernrup M. (1996) Removal of faecal coliforms in a wastewater stabilization pond system in Mindelo, Cape Verde. Water Sci Technol. 34(11): 149-57.

23. Raychaudhuri S., Salodkar S., Sudarshan M. and Thakur A.R. (2007). Integrated Resource Recovery at East Calcutta Wetland: How Safe is These? American Journal of Agricultural and Biological Sciences. 2(2): 75-80. https://doi.org/10.3844/ajabssp.2007.75.80

24. Sengupta A., Rana T., Das B. and Bhattacharjee S. (2012). Wastewater Aquaculture by the Mudialy Fisherman's Cooperative Society in Kolkata, West Bengal: An Example of Sustainable Development, Journal of Applied Aquaculture. 24(2): 137146. 10.1080/10454438.2012.663704

25. Sharma R. (2005). Climate and water resources of India. Curr Sci. 89:818-824.

26. Singh D. (2021). Impact of distillery effluent on Indian major carp, Cirrhinus mrigala. International Journal of Biological Innovations. 3 (1): 221-227.

27. Singh S. and Singh S. (2020). Macrophytes as Bioindicator in Bichhiya River, Rewa (M.P.), India. International Journal of Biological Innovations. 2(1): 25-30.

28. Verma A.K. (2019). Sustainable Development and Environmental Ethics. International Journal on Environmental Sciences. 10 (1): 1-5.

29. Verma A.K. (2021). Influence of climate change on balanced ecosystem, biodiversity and sustainable development: An overview. International Journal of Biological Innovations. 3(2):331-337. https://doi.org/10.46505/ IJBI.2021.3213.

30. Verma A. Kumar and Prakash Sadguru (2018). Haematotoxicity of Phorate, an Organophosphorous pesticide on a 
Freshwater Fish, Channa punctatus (Bloch). International Journal on Agricultural Sciences. 9 (2): 117-120.

31. Verma A.K. and Prakash S. (2020). E-wastes and their impact on environment and public health. International Journal of Applied Research. 6(9): 164-168.
32. WHO (2006). Guidelines for the safe use of wastewater, excreta and greywater, volume 2. Wastewater use in Agriculture. World Health Organization, Geneva. 191p.

33. Yan J. and Honglu Y. (1989). Integrated fish culture management in China. In: Mitsch, J., and Jorgensen, S.E. (eds.) Ecological Engineering. John Wiley and Sons. 375-408p. 